УДК 676.022 .04

\title{
ИЗУЧЕНИЕ ФЕРМЕНТАТИВНОЙ ДЕСТРУКЦИИ КРАХМАЛА В ВОЛОКНАХ МАКУЛАТУРНОЙ МАССЫ
}

\author{
() Е.В. Новожилов", Е.В. Смирнов, Д.Г. Чухчин, А.В. Кондаков
}

\author{
Северный (Арктический) федеральный университет им. М.В. Ломоносова, \\ Набережная Северной Двины, 17, Архангельск, 163002 (Россия), \\ e-mail: biotech@agtu.ru
}

В производстве гофротары используются различные виды крахмалов для повышения прочности, для склейки слоев картона, для поверхностной проклейки. При повторном использовании волокон отработанный крахмал накапливается на поверхности и в микроструктуре вторичных волокон, что приводит к ухудшению свойств бумаги и картона. Селективно действующие препараты амилаз способны удалять из волокна компоненты крахмального связующего, которые снижают водоотдачу волокнистой массы. Наилучший эффект показала смесь амилолитических ферментов.

Ключевые слова: волокна, крахмал, амилазы, фракционирование, ВЭЖХ, электронная микроскопия, обезвоживающая способность.

Исследования выполнены в ЦКП НО «Арктика» (Северный (Арктический) федеральный университет им. М.В. Ломоносова) при финансовой поддержке Минобрнауки России.

\section{Введение}

Основным видом вторичного волокнистого сырья в России является макулатура из гофротары. Отходы производства и потребления гофрированного картона относятся к макулатуре марки МС-5Б. Макулатура этой марки характеризуется содержанием в своем составе большого количества крахмалопродуктов, которые использовались в качестве упрочняющих и склеивающих химических веществ в предшествующем цикле изготовления данного вида картона [1-5].

В бумагу для гофрирования для увеличения ее жесткости добавляют от 0,7 до 1,5\% катионного крахмала [4], есть рекомендации вводить 2-3\% и даже 4-6\% крахмала от волокна [2]. Для поверхностной обработки бумаги на клеильных прессах применяют различные виды крахмалов в количестве 4-7\% от массы бумаги [2]. Отдельные слои гофрокартона склеивают суспензией нативного крахмала, содержащей в своем составе зерна крахмала и крахмальный клейстер [5]. Для некоторых видов картона расход такого крахмального связующего может составлять 2-5\% [4]. Клей на основе алкилдимеркетенов, широко применяемый для проклейки массы в нейтральной среде, также содержит в своем составе катионный крахмал [1]. Отработан-

Новожилов Евгений Всеволодович - заведующий кафедрой биотехнологии, доктор технических наук, профессор, тел.: (8182) 21-89-65,

e-mail: noev50@gmail.com

Смирнов Евгений Валерьевич - аспирант кафедры биотехнологии, тел.: (8182) 21-61-90,

e-mail: noev50@gmail.com

Чухчин Дмитрий Германович - доцент кафедры биотехнологии, кандидат технических наук, тел.: (8182) 21-89-38, e-mail: noev50@gmail.com Кондаков Александр Васильевич - доцент кафедры биотехнологии, кандидат технических наук, тел.: (8182) 21-61-45, e-mail: noev50@ gmail.com ный крахмал накапливается в волокнах и возвращается с ними в цикл производства при повторном использовании гофротары. Таким образом, общее содержание крахмала в гофротаре может быть очень высоким.

Восстановление волокнами бумагообразующих свойств, утраченных при многократном использовании макулатуры, серьезная проблема, требующая комплексного подхода для ее решения. Одной из причин, не позволяющих в полной мере реализовать весь потенциал свойств вторичных волокон, является наличие отработанного крахмального связующего.

\footnotetext{
* Автор, с которым следует вести переписку.
} 
Выяснению роли отработанного крахмала в технологии макулатуры из гофротары посвящен ряд работ [4, 6-9]. Тем не менее в недавно опубликованной монографии Д.А. Дулькина с соавторами [1] отмечается, что влияние крахмала, содержащегося в картонно-бумажной продукции, на ее повторную переработку исследовано недостаточно.

При переработке макулатуры крахмалопродукты частично остаются на волокне, частично переходят в окружающую волокна жидкость, что приводит к их накоплению в массе и оборотной воде при повторных циклах использования. Распределение крахмала в суспензии макулатурной массы, которая является сложной многокомпонентной системой, меняется в процессе подготовки массы. В реальных условиях производства старый крахмал может находиться в ненабухшем или малонабухшем состоянии внутри волокон, в сильно набухшем состоянии на поверхности волокон и в растворенном или диспергированном состоянии в оборотной воде. Считается [4], что при разволокнении макулатуры в холодной воде, что характерно для большинства российских фабрик, основная часть крахмалопродуктов на этом этапе подготовки массы остается связанной с волокном. Промывки и сгущения дезинтегрированной массы из макулатуры недостаточно, чтобы в полной мере очистить волокно от крахмала [6]. Процесс подготовки макулатурной массы далее предусматривает использование размола массы. Механическое воздействие вызывает удаление крахмала с поверхности вторичных волокон. В результате наблюдается увеличение степени загрязненности оборотных вод, повышение показателя химического потребления кислорода (ХПК) становится особенно заметным при степени помола массы выше $30^{\circ}$ ШР [6].

Переход крахмального связующего гофрокартона из макулатурной массы в водную среду можно интенсифицировать за счет ферментативных обработок. Известно несколько видов амилаз, которые оказывают различное деструктирующее действие на природный и модифицированный крахмалы. Для применения в бумажной промышленности ранее предлагались $\alpha$-амилаза [4, 6-8] и глюкоамилаза [9].

В технологии подготовки макулатурной массы все шире применяется фракционирование, которое позволяет существенно повысить качество продукции, снизить потери мелкого волокна, сэкономить энергию и увеличить производительность технологического потока [1]. Длинноволокнистая (ДВФ) и коротковолокнистая (КВФ) фракции различаются не только по параметрам и свойствам волокон, но и по содержанию крахмала. В КВФ макулатурной массы содержится больше крахмалопродуктов, оставшихся после предыдущих циклов переработки. Это объясняется тем, что адсорбция крахмала лучше идет на мелких волокнах из-за большей площади поверхности.

Целями данной работы являлись исследование степени удаления крахмала, определение состава продуктов его деструкции при обработке амилолитическими ферментами фракций макулатурной массы из гофротары, а также оценка влияния ферментативной обработки на способность волокон к обезвоживанию.

\section{Экспериментальная часть}

В экспериментах использовали пробы длинноволокнистой (ДВФ) и коротковолокнистой (КВФ) фракций макулатурной массы Сухонского ЦБК. Примерное соотношение между ДВФ и КВФ составляет 70-80 : 20-30. Пробы фракций были отжаты до сухости 27-29\%, для проведения опытов их разбавляли до заданной концентрации дистиллированной водой. Для обработки использовали коммерческие препараты $\alpha$-амилазы, глюкоамилазы и их смеси производства компании Novozymes A/S (Дания).

Ферментативную обработку проводили при концентрации массы $3 \%$, температуре $50{ }^{\circ} \mathrm{C}$ в течение 3 ч с расходом ферментов 1 кг/т волокна. Значение $\mathrm{pH}$ массы находилось в пределах 7,2-7,8, перед обработкой ферментами ее подкисляли уксусной кислотой до $\mathrm{pH}$ 6. После обработки волокно отделяли на фильтре, промывали дистиллированной водой. Для оценки влияния деструкции крахмала на свойства фракций массы определяли степень помола и обезвоживающую способность на аппарате Шоппер - Риглеpa. Для исследования поверхности волокон с применением электронного микроскопа ZEISS «SIGMA VP» их высушивали методом лиофильной сушки.

В фильтратах определяли содержание общих РВ. Растворимые продукты деструкции крахмала изучали методом ВЭЖХ с использованием хроматографа «Стайер». Состав олигосахаридов определяли на колонке Rezex RSO-Oligosaccharide $\mathrm{Ag}^{+}$(4\%). Далее проводили инверсию продуктов ферментативного гидролиза 2\%-ной соляной кислотой. Концентрацию глюкозы определяли на колонке Rezex RPMMonosacharide $\mathrm{Pb}^{2+}(8 \%)$. 


\section{Обсуждение результатов}

Макулатура после роспуска в гидроразбивателе представляет собой водноволокнистую суспензию, содержащую волокна различной длины. Фракционирование волокнистой массы позволяет разделить ее на ДВФ и КВФ, что дает возможность раздельно обрабатывать фракции и оперировать ими в технологии изготовления бумаги и картона.

Волокна двух фракций макулатуры из гофротары различаются по составу и свойствам. ДВФ содержит преимущественно длинные и грубые хвойные сульфат-целлюлозные волокна, которые имеют более низкую степень помола, труднее размалываются. В КВФ представлены в основном короткие волокна лиственной нейтрально-сульфитной полуцеллюлозы, в состав этой фракции входят также сульфатцеллюлозные волокна, сильно разрушенные и укороченные в процессе предыдущих циклов переработки.

a)

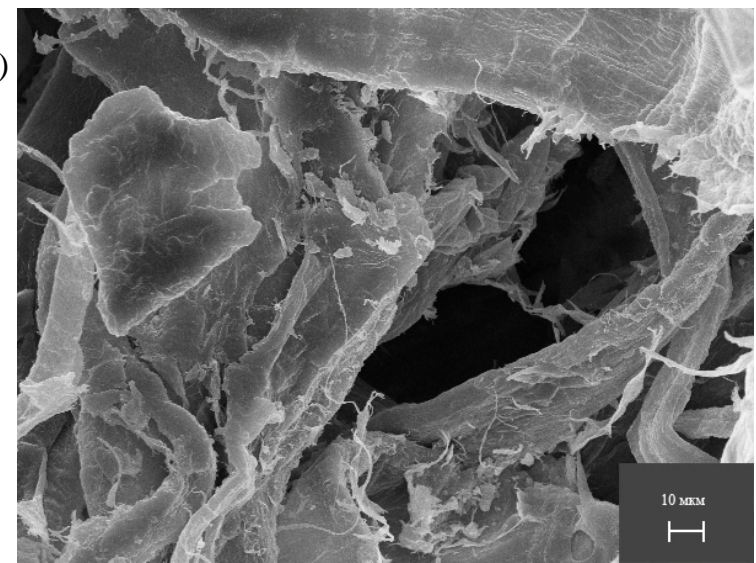

B)

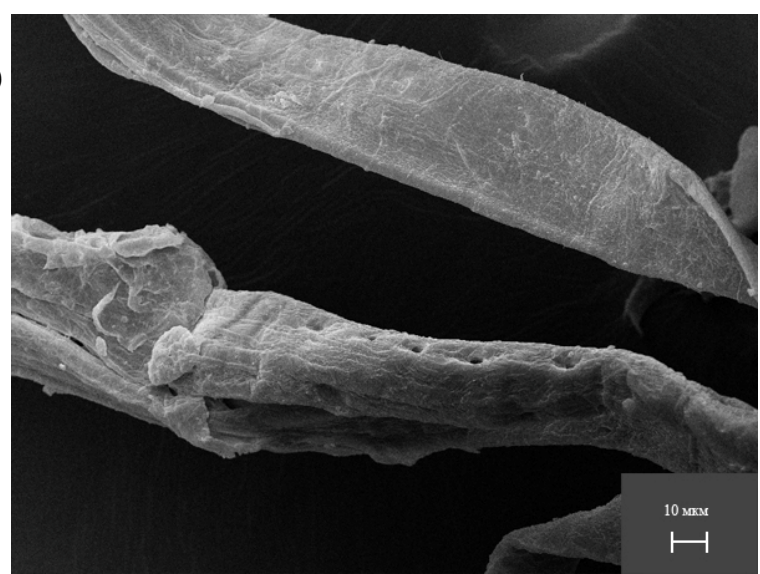

Д)

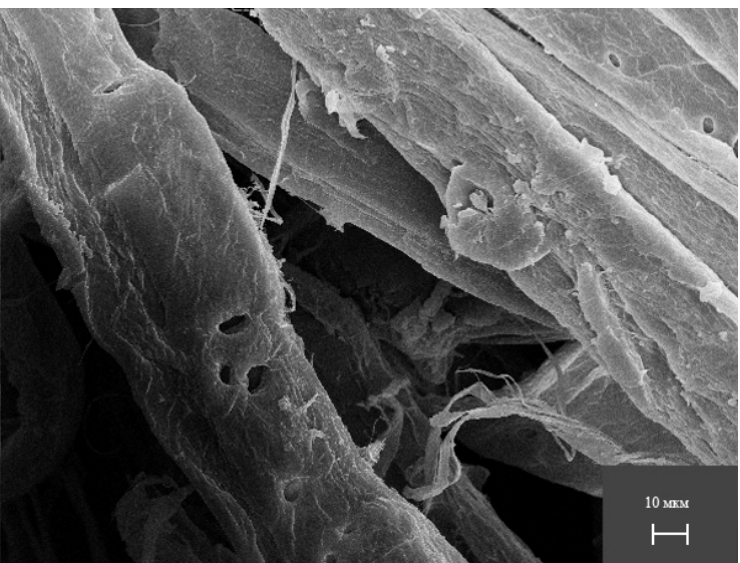

б)

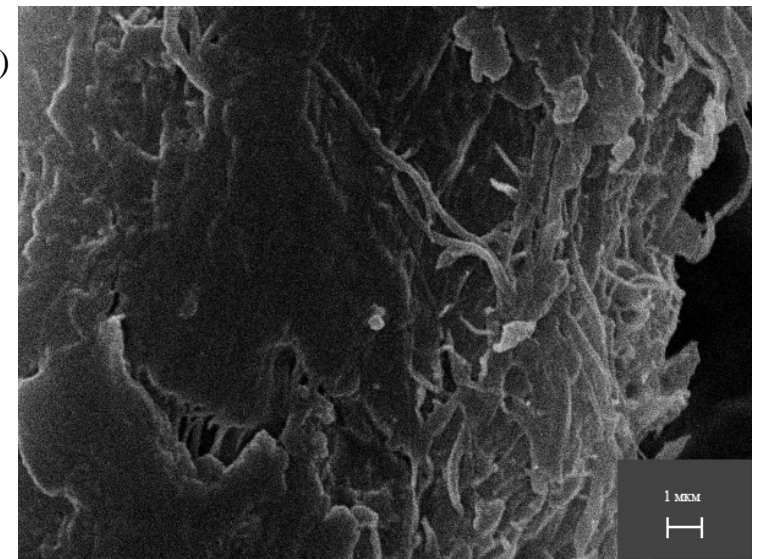

г)

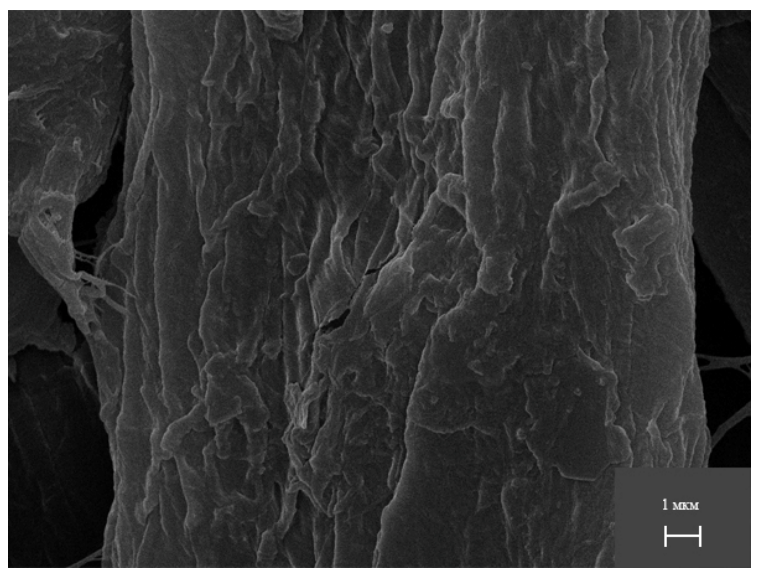

e)

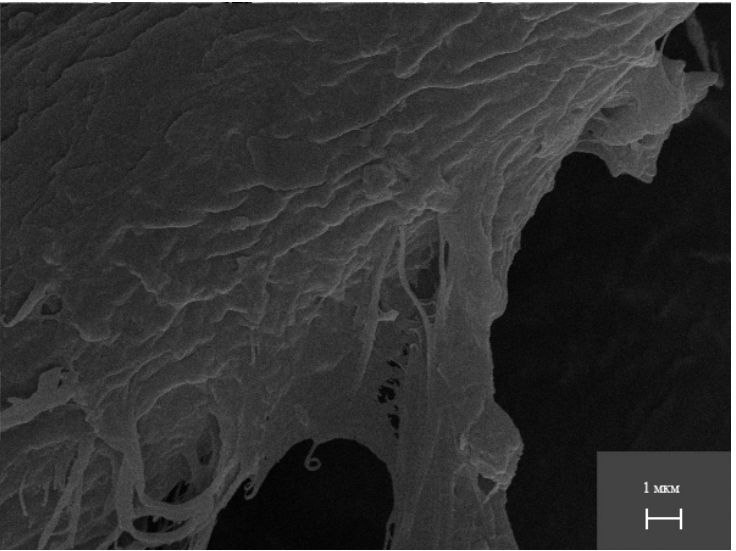

Рис. 1. Фотографии волокон различных фракций макулатурной массы КВФ без размола: а) и б); ДВФ до размола: в) и г); ДВФ после размола: д) и е) 
Фотографии волокон сделаны на электронном микроскопе с различным увеличением (рис. 1). Образцы были высушены методом лиофильной сушки, что позволило лучше сохранить структурные особенности компонентов КВФ и ДВФ. Очевидны различия в степени разработки волокон разных фракций. Расслоение и ослабление структуры клеточной стенки более выражено у волокон КВФ (рис. 1а, б). Волокна ДВФ менее разрушены, четко наблюдаются элементы фибриллярной структуры слоев клеточной стенки (рисунок 1в, г). В целом на фотографиях наблюдается достаточно чистая поверхность волокон, следует отметить отсутствие на ней видимых фрагментов отработанного крахмального связующего.

При интенсивном размоле вторичных волокон происходит очистка их от значительной части загрязнений. Однако на большинстве отечественных бумажных фабрик применяется слабый размол массы с увеличением степени помола всего на 2-4 ${ }^{\circ} Ш Р$. При таком размоле степень разработки волокна ДВФ усиливается, как это видно на фото (рис. 1д, е), но этого воздействия недостаточно, чтобы обеспечить значительное удаление крахмала и других загрязнений из волокна.

В работе было оценено действие $\alpha$-амилазы, глюкоамилазы и их смеси на удаление крахмала из волокна. Степень деструкции крахмального связующего зависит от его доступности и напрямую связана со специфическим механизмом действия амилолитических ферментов. Альфа-амилаза произвольно расщепляет связи в макромолекулах крахмала, в результате его молекулярная масса быстро снижается. Продуктами деструкции являются относительно низкомолекулярные фрагменты - декстрины, которые могут как переходить в раствор, так и оставаться связанными с поверхностью волокна. Глюкоамилаза отщепляет в крахмале элементарные звенья с конца макромолекул, в результате чего в раствор переходит глюкоза, а степень полимеризации остаточного крахмала снижается гораздо медленнее, чем при действии $\alpha$-амилазы. Смесь амилолитических ферментов способна постепенно полностью деструктировать макромолекулы крахмала.

В данном исследовании при отборе и сгущении проб фракций с оборотной водой было удалено основное количество растворенного крахмала. Действие ферментов в основном распространялось на крахмальное связующее, локализованное в волокнах КВФ и ДВФ.

Хроматограммы фильтратов КВФ, отобранных из фракций макулатурной массы после их обработки амилолитическими ферментами, представлены на рисунке 2. Аналогичные по виду хроматограммы получены для фильтратов из ДВФ.

a)

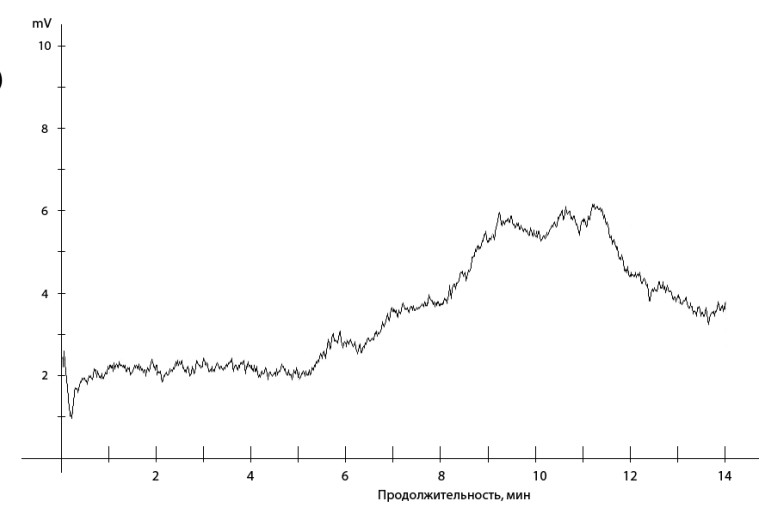

B)

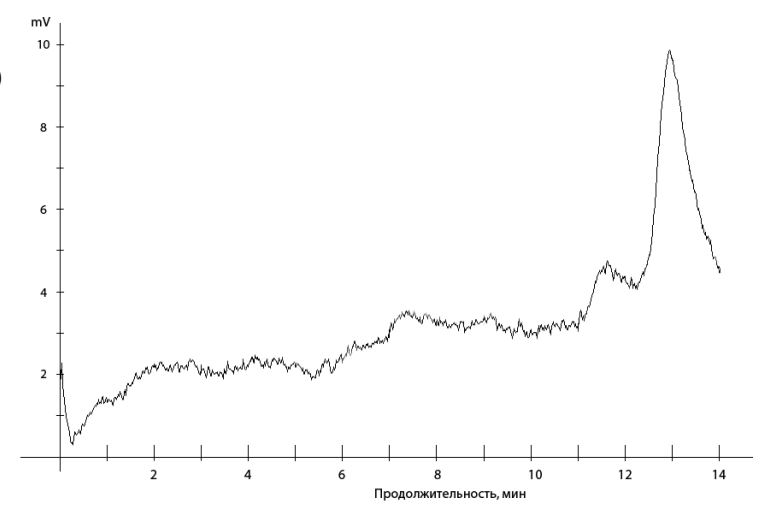

б)

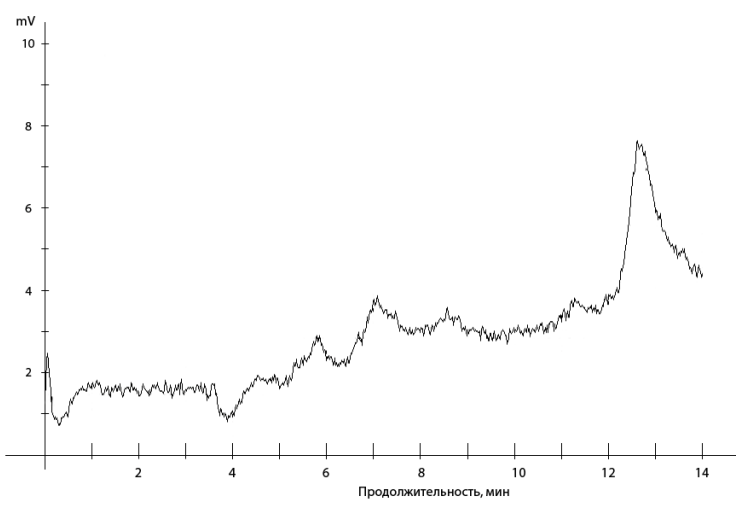

Рис. 2. Хроматограмма фильтратов КВФ, обработанных $\alpha$-амилазой (а), глюкоамилазой (б), смесью $\alpha$-амилазы и глюкоамилазы (в) 
Специфические механизмы действия $\alpha$-амилазы и глюкоамилазы привели к получению продуктов деструкции различного состава. При действии $\alpha$-амилазы крахмал разрушается только частично, в фильтрате накапливаются продукты в виде декстринов различной степени полимеризации. В дальнейшем может происходить их агломерация в более крупные фрагменты, усиливающие анионную загрязненность массы.

Пик на хроматограмме по оси абсцисс в районе 13 мин характеризует наличие в фильтрате глюкозы. В фильтратах из контрольных проб (без обработки ферментами) глюкозу обнаружить не удалось, она не была найдена и в пробе производственной оборотной воды. Глюкоза появляется в растворе только при обработке фракций глюкоамилазой или смесью $\alpha$-амилазы и глюкоамилазы. Можно отметить также наличие в фильтратах в небольшом количестве целлобиозы (пик в районе 11 мин).

Чтобы определить количество растворенных углеводов, провели инверсию продуктов ферментативного гидролиза и определили содержание общих РВ. Как видно из таблицы 1, прирост содержания общих РВ в фильтратах наблюдался и после обработки $\alpha$-амилазой, и после обработки глюкоамилазой, однако больше углеводов обнаружено в растворе после действия смеси амилолитических ферментов. В целом снижение выхода за счет растворения крахмала было незначительным - до 0,2-0,3\% от волокна (по общим PB).

По данным хроматографического анализа рассчитано содержание глюкозы в фильтратах в расчете на 1 г волокна (табл. 1). Очевидно, что глюкоамилаза разрушает крахмал медленнее, чем $\alpha$-амилаза, но при этом доступный для действия фермента крахмал разрушается в большей степени, так как образуются не декстрины, а мономер. Деструкция крахмального связующего до глюкозы наиболее интенсивно происходит при обработке смесью амилолитических ферментов, больше глюкозы найдено в фильтрате из КВФ.

В ранее выполненном исследовании [10] ферментативную обработку фракций проводили теми же препаратами, но расход их был значительно выше - 5-7 кг/т волокна. В результате количество растворенного материала было больше, однако и в этом случае потери выхода за счет растворения крахмала оставались низкими - до 0,5\% от волокна. Очевидно, что при ферментативной деструкции амилазами сохраняются общие тенденции: больше крахмалопродуктов удаляется из волокон КВФ, наиболее интенсивно это происходит при обработке $\alpha$-амилазой, а также при действии смеси амилолитических ферментов. В целом растворение углеводов в процессе обработки ферментами было небольшим, что свидетельствует об ограниченной деструкции крахмала только на поверхности волокна и недоступности остальной части крахмала, находящегося во внутренних структурах клеточных стенок волокон, для действия амилолитических ферментов.

Несмотря на то, что ферментативной деструкции подвергается только очень небольшая часть крахмала, связанного с волокном, происходит изменение некоторых свойств волокон разных фракций. Известно [6-9], что отрицательное влияние отработанного крахмала проявляется в ухудшении обезвоживания макулатурной массы, что во многом связано с его набуханием в водной среде. Это вызывает завышение степени помола водноволокнистой суспензии по сравнению со степенью помола волокна.

Фракции макулатурной массы изначально различаются по степени помола и способности к обезвоживанию (табл. 2).

Таблица 1. Содержание общих РВ и глюкозы в фильтратах после обработки амилолитическими ферментами фракций макулатурной массы

\begin{tabular}{|c|c|c|c|}
\hline Фермент & $\begin{array}{c}\text { Выход общих РВ, } \\
\text { мг/г волокна }\end{array}$ & $\begin{array}{c}\text { Прирост общих РВ, } \\
\text { мг/г волокна }\end{array}$ & $\begin{array}{c}\text { Выход глюкозы, } \\
\text { мг/г волокна }\end{array}$ \\
\hline \multicolumn{4}{|c|}{ Длинноволокнистая фракция } \\
\hline Контроль (без ферментов) & 3,0 & - & Нет \\
\hline$\alpha$-амилаза & 5,4 & 2,4 & Нет \\
\hline Глюкоамилаза & 4,2 & 1,2 & 0,6 \\
\hline Смесь ферментов & 5,7 & 2,7 & 1,1 \\
\hline \multicolumn{4}{|c|}{ Коротковолокнистая фракция } \\
\hline Контроль (без ферментов) & 2,6 & - & Нет \\
\hline$\alpha$-амилаза & 5,3 & 2,7 & Нет \\
\hline Глюкоамилаза & 3,2 & 0,6 & 0,8 \\
\hline Смесь & 6,8 & 3,2 & 1,3 \\
\hline
\end{tabular}


Таблица 2. Влияние обработки амилолитическими ферментами на степень помола и обезвоживающую способность фракций макулатурной массы

\begin{tabular}{|c|c|c|c|c|c|}
\hline \multirow{2}{*}{ Фермент } & \multirow{2}{*}{ Степень помола, ${ }^{\circ} Ш Р$} & \multicolumn{4}{|c|}{ Обезвоживающая способность, с } \\
\hline & & 300 мл & 500 мл & 700 мл & 800 мл \\
\hline \multicolumn{6}{|c|}{ Длинноволокнистая фракция } \\
\hline- & 19 & 2 & 7 & 17 & 28 \\
\hline$\alpha$-амилаза & 20 & 2 & 7 & 16 & 27 \\
\hline Глюкоамилаза & 19 & 2 & 7 & 16 & 27 \\
\hline Смесь амилаз & 19 & 2 & 6 & 15 & 25 \\
\hline \multicolumn{6}{|c|}{ Коротковолокнистая фракция } \\
\hline- & 31 & 8 & 28 & 65 & 106 \\
\hline$\alpha$-амилаза & 32 & 10 & 31 & 72 & 114 \\
\hline Глюкоамилаза & 29 & 8 & 27 & 63 & 100 \\
\hline Смесь амилаз & 30 & 9 & 29 & 66 & 104 \\
\hline
\end{tabular}

В данном исследовании основное количество оборотной воды было предварительно отделено от волокна. При обработке волокон фракций амилолитическими ферментами изменение степени помола массы было небольшим или совсем отсутствовало. Ранее сообщалось $[4,6]$, что разрушение крахмала $\alpha$-амилазой с последующим удалением продуктов его деструкции значительно улучшает водоотдачу, однако в этих исследованиях проводили ферментативную обработку суспензии волоконистой массы. В этом случае действие фермента распространялось не только на крахмал, оставшийся в волокнах, но и на крахмал, растворенный в оборотной воде.

КВФ имеет бо́льшую активную поверхность волокон, легче адсорбирует и удерживает различные химикаты (крахмал, клей) в сравнении с ДВФ, при меньшей водоотдаче имеет повышенную способность к гидратации и набуханию [1]. При небольшом расходе ферментов, несмотря на удаление части крахмала при действии $\alpha$-амилазы, обезвоживающая способность КВФ ухудшилась по сравнению с контролем. Это связано с тем, что частичное разрушение крахмала $\alpha$-амилазой активизирует процессы его набухания на волокне [11].

При действии глюкоамилазы процесс деструкции крахмала идет медленнее, однако при этом крахмал разрушается полностью до глюкозы. Вероятно, в этом случае набухание крахмала происходит в меньшей степени, что сопровождается снижением степени помола массы и улучшением ее водоотдачи по сравнению с контролем. Использование смеси амилаз дает синергический эффект и приводит к максимальному повышению обезвоживающей способности фракций макулатурной массы.

\section{Выводы}

1. Селективно действующие препараты амилаз способны удалять из волокон макулатурной массы компоненты крахмального связующего. В наибольшей степени деструкция крахмала происходит при использовании смеси амилолитических ферментов. Действие амилаз из-за больших размеров их молекул ограничено только поверхностью волокон.

2. При расходе амилолитических ферментов 1 кг/т волокна снижение выхода за счет растворения продуктов деструкции крахмала составляет 0,2-0,3\%. Ферментативная обработка оказывает незначительное влияние на свойства ДВФ, изменения в большей степени проявляются при обработке КВФ, волокна которой содержат больше отработанного крахмала.

3. Использование глюкоамилазы и смеси амилаз приводит к улучшению обезвоживающей способности фракций макулатурной массы. При деструкции крахмала $\alpha$-амилазой имеет место снижение водоотдачи, предположительно, из-за набухания крахмала, оставшегося на поверхности волокна.

\section{Список литературь}

1. Дулькин Д.А., Спиридонов В.А., Комаров В.И. Современное состояние и перспективы использования вторичного волокна из макулатуры в мировой и отечественной индустрии бумаги. Архангельск, 2007. 1118 с.

2. Южанинова Л.А., Дулькин Д.А., Спиридонов В.А., Комаров В.И. Особенности технологии бумаги-основы для гофрирования из макулатуры и требования к ее потребительским свойствам. Архангельск, 2007. 103 с.

3. Копыльцов А.А. Опыт применения катионных крахмалов при производстве бумаги и картона из макулатуры // Технология переработки макулатуры : труды 6-й научн.-техн. конф. Караваево; Правда, 2005. С. 120-123. 
4. Лапин В.В., Смоляков А.И., Кудрина Н.Д. Проблема прочностных свойств бумаги для гофрирования и картона для плоских слоев из 70-100\% макулатуры: роль помола // Целлюлоза. Бумага. Картон. 2002. №9-10. С. 32-34.

5. Идиатуллин А.М., Баранова Н.А., Дереза Н.Н., Полканова Н.Л., Ефременко Ю.В., Грачев С.Г. О технологии приготовления клея для гофрокартона // Технология переработки макулатуры : труды 6-й научн.-техн. конф. Караваево; Правда, 2005. С. 37-40.

6. Лапин В.В., Смоляков А.И., Кудрина Н.Д. Загрязнения в бумажной массе из $100 \%$ макулатуры: влияние на степень помола и прочность бумаги и картона // Целлюлоза. Бумага. Картон. 2001. №7-8. С. 32-34.

7. Яблочкин Н.И., Ковернинский И.Н., Овчинников М.Д., Дулькин Д.А. Проблема переработки макулатуры, содержащей катионные и анионные виды крахмалов // Технология переработки макулатуры : труды 6-й научн.-техн. конф. Караваево; Правда, 2005. С. 19-21.

8. Кулешов, А.В., Смолин А.С., Новожилов Е.В., Кондаков А.В. Характеристика макулатурного волокна после ферментативного удаления крахмала // Известия вузов. Лесной журнал. 2009. №5. С. 115-120.

9. Новожилов Е.В., Кондаков А.В., Чертовская В.П. Развитие прочностных свойств вторичных волокон: роль отработанного крахмального связующего // Новейшие технологии в производстве бумаги из макулатурного сырья и переработке гофрокартона : труды 10-й юбилейной Междун. научн.-техн. конфер. Караваево, 2009. С. 2-88.

10. Новожилов Е.В., Кондаков А.В., Пошина Д.Н., Чертовская В.П. Ферментативная модификация фракций макулатурной массы из гофротары // Известия вузов. Лесной журнал. 2010. №4. С. 106-115.

11. Кондаков А.В., Новожилов Е.В. Изучение кинетики поглощения воды макулатурой из гофротары // Новые достижения в химии и химической технологии растительного сырья : материалы IV Bcepoc. конф. Барнаул, 2009. Кн. 1. C. $251-252$.

Поступило в редакцию 19 декабря 2012 2.

Novozhilov E.V., Smirnov E.V., Chuhchin D.G., Kondakov A.V. STUDY OF ENZYMATIC DESTRUCTION OF STARCH INTO THE RECYCLED FIBERS

Northern (Arctic) Federal University named after Lomonosov, Naberezhnaja Severnoj Dviny, 17, Arkhangelsk, 163002

(Russia), e-mail: biotech@agtu.ru

Different types of starches used to improve strength for bonding layers of cardboard, for surface sizing in the production of corrugated board. If reusing the waste fiber starch accumulates on the surface and in the microstructure of the secondary fibers, which leads to deterioration of the properties of paper and paperboard. Selectively acting amylases products are able to remove components of starch binder from fiber, which reduce drainage of secondary fiber. The best effect showed a mixture of amylolytic enzymes.

Keywords: fibers, starch, amylase, fractionation, HPLC, electron microscopy, dewatering capacity.

\section{References}

1. Dul'kin, D.A., Spiridonov V.A., Komarov V.I. Sovremennoe sostojanie i perspektivy ispol'zovanija vtorichnogo volokna iz makulatury $v$ mirovoj i otechestvennoj industrii bumagi. [Current status and prospects for the use of recycled fibers from recovered paper in the global and domestic paper industry]. Arkhangelsk, 2007, 1118 p. (in Russ.).

2. Juzhaninova, L.A., Dul'kin D.A., Spiridonov V.A., Komarov V.I. Osobennosti tehnologii bumagi-osnovy dlja gofrirovanija iz makulatury i trebovanija $k$ ee potrebitel'skim svojstvam. [Technology features of the base paper fluting paper and requirements for its consumer properties]. Arkhangelsk, 2007, 103 p. (in Russ.).

3. Kopyl'cov A.A. Tehnologija pererabotki makulatury: trudy 6 nauchn.-tehn. konf. [The technology of waste paper: Works 6 Scientific and Technical Conference]. Karavaevo; Pravda, 2005, pp. 120-123. (in Russ.).

4. Lapin V.V., Smoljakov A.I., Kudrina N.D. Celljuloza. Bumaga. Karton, 2002, no. 9-10, pp. 32-34. (in Russ.).

\footnotetext{
* Corresponding author.
} 
5. Idiatullin A.M., Baranova N.A., Dereza N.N., Polkanova N.L., Efremenko Ju.V., Grachev S.G. Tehnologija pererabotki makulatury: trudy 6 nauchn.-tehn. konf. [The technology of waste paper: Works 6 Scientific and Technical Conference]. Karavaevo; Pravda, 2005, pp. 37-40. (in Russ.).

6. Lapin V.V., Smoljakov A.I., Kudrina N.D. Celljuloza. Bumaga. Karton, 2001, no. 7-8, pp. 32-34. (in Russ.).

7. Jablochkin, N.I., Koverninskij I.N., Ovchinnikov M.D., Dul'kin D.A. Tehnologija pererabotki makulatury: trudy 6 nauchn.-tehn. konf. [The technology of waste paper: Works 6 Scientific and Technical Conference]. Karavaevo; Pravda, 2005, pp. 19-21. (in Russ.).

8. Kuleshov, A.V., Smolin A.S., Novozhilov E.V., Kondakov A.V. Izvestija vuzov. Lesnoj zhurnal, 2009, no. 5, pp. 115-120. (in Russ.).

9. Novozhilov E.V., Kondakov A.V., Chertovskaja V.P. Novejshie tehnologii v proizvodstve bumagi iz makulaturnogo syr'ja $i$ pererabotke gofrokartona: trudy 10 jubilejnoj mezhdunarodnoj nauchn.-tehn. konfer. [The latest technology in the manufacture of paper from waste paper and cardboard recycling: proceedings of the 10th anniversary of the international scientific conference]. Karavaevo, 2009, pp. 2-88. (in Russ.).

10. Novozhilov E.V., Kondakov A.V., Poshina D.N., Chertovskaja V.P. Izvestija vuzov. Lesnoj zhurnal, 2010, no. 4, pp. 106-115. (in Russ.).

11. Kondakov A.V., Novozhilov E.V. Novye dostizhenija v himii i himicheskoj tehnologii rastitel'nogo syr'ja: mate-rialy IV vseros. konf. [New advances in chemistry and chemical engineering plant materials: materials of the IV All-Russian Conference]. Barnaul, 2009, Book 1, pp. 251-252. (in Russ.). 